\section{Properly Timing Foliar-applied Fertilizers Increases Efficacy: A Review and Update on Timing Foliar Nutrient Applications to Citrus and Avocado}

\author{
Carol J. Lovatt ${ }^{1}$
}

ADDITIONAL INDEX WORDs. alternate bearing, boron, nitrate, potassium, phosphate, phosphite, sulfate, urea

SUMMARY. Foliar fertilization efficiently meets the nutrient demand of tree fruit crops during periods when soil conditions (low or high temperatures, low or excess soil moisture, $\mathrm{pH}$, salinity) render soil-applied fertilizers ineffective, when nutrients (e.g., phosphate, potassium, and trace elements) become fixed in the soil, and when tree nutrient demand is high. Applying nutrients directly to leaves ensures that the metabolic machinery of the tree is not compromised by low availability of an essential nutrient. It should be noted that phloem mobile nutrients applied to the foliage are translocated to all tree parts, even feeder roots. Because foliar application of fertilizers can reduce nutrient accumulation in soil, runoff water, surface water (streams, lakes, ocean), and groundwater (drinking water supply), where they contribute to salinity, eutrophication, or nitrate contamination, with negative consequences to the environment and humans, it is highly desirable to replace soilapplied fertilizers at least in part with foliar-applied fertilizers. However, not all nutrients are taken up through leaves and, even if taken up, some nutrients are not phloem mobile. In addition, although foliar fertilizer rates are typically lower than soil fertilizer rates, application can be more costly. The goal has been to time the application of foliar fertilizers to key stages of citrus (Citrus sp.) and avocado (Persea americana) tree phenology when demand for the nutrient is likely to be high and especially when soil conditions are likely to compromise nutrient uptake by roots. This approach has proven successful for increasing yield, fruit size, and grower income even when the tree is not nutrient deficient by standard leaf analysis. Winter prebloom foliar-applied low-biuret urea was previously documented to increase total yield of both navel and 'Valencia' oranges (Citrus sinensis). Adaptation of this treatment to 'Nules' Clementine mandarin (Citrus reticulata) increased the yield of commercially valuable size fruit in two experiments. Foliar application of boron or low-biuret urea to 'Hass' avocado trees at the "cauliflower" stage of inflorescence development increased total yield; potassium phosphite applied at this stage of tree phenology increased the yield of commercially valuable size fruit.

$\mathrm{F}$ oliar fertilization is a rapid and efficient way to improve crop nutrient status during periods

Professor of Plant Physiology, Department of Botany and Plant Sciences-072, University of California, Riverside, CA 92521-0124

This research was supported in part by the California Department of Food and Agriculture Fertilizer Research and Education Program, California Citrus Research Board, California Avocado Commission, and Citrus Research Center and Agricultural Experiment Station of the University of California, Riverside. The author thanks Yusheng Zheng, Toan Khuong, and Eric Jorgenson for their technical assistance and University of California Cooperative Extension Farm Advisors Robert Beede (King's County) and Ben Faber (Ventura and Santa Barbara Counties); Robert Krueger, Horticulturist and Curator, USDA-ARS National Clonal Germplasm Repository for Citrus and Dates; and Lauren Garner, Professor of Horticulture, California Polytechnical State University, for their contributions to the manuscript.

The mention of a trademark, proprietary product, or vendor does not constitute an endorsement by University of California, Riverside, to the exclusion of other products or vendors that may also be suitable.

${ }^{1}$ Corresponding author. E-mail: carol.lovatt@ucr.edu. of high nutrient demand in the phenology of a tree crop, or when soil conditions (cold wet soils in spring, hot dry soils in summer, lack of precipitation under rainfed conditions, salinity, $\mathrm{pH}$ ) during the growing season render soil nutrients and hence soil-applied fertilizers less available to the plant. Foliar fertilization provides the nutrients required for photosynthesis and other important metabolic functions to prevent restrictions in carbon fixation, metabolism, and plant productivity. Even a transient or incipient deficiency needs to be corrected quickly. The longer the nutrient status of the tree remains at the low end or below the optimal range at key stages of phenology, the greater the negative effects on yield, fruit size, quality, and next year's bloom.

A priori knowledge (research) is necessary to develop a foliar fertilization program for a crop. Not all nutrients are taken up through leaves and, even if taken up, some nutrients are not phloem mobile. For deciduous fruit crops, reproductive growth commences before vegetative shoot extension and leaf expansion. Thus, foliar fertilization strategies at early stages of tree phenology, by default, target reproductive structures, which are typically small. Many crop plants have a thick waxy cuticle known to compromise uptake of some foliar-applied nutrients once the leaves mature (Kallsen, 2007). For foliar fertilization to be cost effective, the applied nutrient must be taken up by the leaves of the crop, or other target organs, and be phloem mobile. Foliar fertilization with nutrients meeting these criteria are 5 to 30 times more efficient than soil fertilization, depending on the nutrient, crop, and soil in which the crop is growing (PureGro Co., n.d.). Foliar fertilization can save the grower money over soil fertilization because the amount of a nutrient applied to the foliage is significantly lower than the amount that must be applied to the soil to achieve the same yield (PureGro Co., n.d.). The cost of foliar fertilization is frequently associated with application cost. However, by properly timing the application of foliar fertilizers to key stages of crop phenology when nutrient demand is likely to be high or when soil conditions are known to restrict nutrient uptake, a yield benefit and net increase

\begin{tabular}{llll}
\hline $\begin{array}{l}\text { Units } \\
\text { To convert U.S. to SI, } \\
\text { multiply by }\end{array}$ & U.S. unit & SI unit & $\begin{array}{l}\text { To convert SI to U.S., } \\
\text { multiply by }\end{array}$ \\
\hline 0.4047 & acre $(\mathrm{s})$ & $\mathrm{ha}$ & 2.4711 \\
9.3540 & gal/acre & $\mathrm{L} \cdot \mathrm{ha}^{-1}$ & 0.1069 \\
2.54 & inch $(\mathrm{es})$ & $\mathrm{cm}$ & 0.3937 \\
0.4536 & $\mathrm{lb}$ & $\mathrm{kg}$ & 2.2046 \\
1.1209 & $\mathrm{lb} / \mathrm{acre}$ & $\mathrm{kg} \cdot \mathrm{ha}^{-1}$ & 0.8922 \\
28.3495 & $\mathrm{Oz}$ & $\mathrm{g}$ & 0.0353 \\
6.8948 & $\mathrm{psi}$ & $\mathrm{kPa}$ & 0.1450 \\
$\left({ }^{\circ} \mathrm{F}-32\right) \div 1.8$ & ${ }^{\circ} \mathrm{F}$ & ${ }^{\circ} \mathrm{C}$ & $\left({ }^{\circ} \mathrm{C} \times 1.8\right)+32$ \\
& & & \\
\end{tabular}


in grower income has been achieved, typically with only one application, for both evergreen and deciduous tree fruit crops, including citrus (Albrigo, 1999; Ali and Lovatt, 1994; Boman. 2002), avocado (Jaganath and Lovatt, 1998; Lovatt, 1999), banana [Musa sp. (Kumar and Kumar, 2007)], date palm [Phoenix dactylifera (Khayyat et al., 2007)], mango [Mangifera indica (Saran and Kumar, 2011)], olive [Olea europaea (Talaie and Taheri, 2001)], apple [Malus domestica (Stampar et al., 1999; Stover et al., 1999; Wargo et al., 2003; Wojcik et al., 2008)], pear [Pyrus sp. (Batjer and Thompson, 1949)], pistachio [Pistacia vera (Brown et al., 1995)], almond [Prunus amygdalus (Sotomayor et al., 2002)], and pecan [Carya illinoinensis (Wells et al., 2008)]. More recently, the economic benefits of foliar fertilizers have been documented for annual fruit crops such as cantaloupe [Cucumis melo (Lester et al., 2007)] and grains; e.g., rice [Oryza sativa (Son et al., 2012)].

Replacing soil-applied fertilizer with foliar-applied fertilizer contributes to fertilizer best management practices and reduces the potential for accumulation of nutrients in soil, runoff water, surface water (streams, lakes, and the ocean), and groundwater (drinking water supply), where they can contribute to salinity, eutrophication, and nitrate contamination in the case of nitrogen $(\mathrm{N})$, all of which have serious consequences on human health and the environment. With less water of good quality available to leach accumulating nutrient (fertilizer) salts from orchard soils, cost-effective foliar fertilization strategies that replace a portion of the fertilizer applied to the soil will contribute to the sustainability of the tree-fruit industries.

The goal has been to identify the role that essential nutrients play in the physiology of a tree crop and then to apply that nutrient as a foliar fertilizer at the appropriate time in the phenology of the tree; i.e., a time when the demand for the nutrient is likely to be high, to stimulate a specific physiological process that increases yield, fruit size, or fruit quality. With this knowledge, foliar application of a fertilizer can result in a net increase in grower income, even when the tree is not deficient in the nutrient by standard leaf analysis (Lovatt, 1999). For sweet orange cultivars, a single winter prebloom foliar application of low-biuret urea (50-54 lb/acre, 46\% $\mathrm{N}, \leq 0.25 \%$ biuret), at about the initiation of floral organogenesis (Lord and Eckard, 1987), increased flower number and total yield per tree and juice total soluble solids (TSS) of 'Valencia' juice orange trees in Florida (Albrigo, 1999). This treatment also increased total yield and yield of commercially valuable size fruit (2.73.1 inches transverse diameter) of the 'Washington' navel grown in California for the fresh fruit market (Ali and Lovatt, 1994). In addition, winter prebloom foliar-applied phosphite $(0.5$ gal/acre, $0 \mathrm{~N}-17.5 \mathrm{P}-0 \mathrm{~K})$ increased 'Valencia' orange floral intensity, total yield, and pounds solids per tree (Albrigo, 1999). Foliar application of low-biuret urea or potassium phosphite (0.49 gal/acre, $0 \mathrm{~N}-12.2 \mathrm{P}-$ $21.6 \mathrm{~K})$ at maximum peel thickness, which marks the end of the cell division stage in citrus fruit development, significantly increased the yield of commercially valuable large fruit (2.7-3.5 inches transverse diameter) of 'Frost nucellar' navel orange (Lovatt, 1999). Due to the poor uptake of foliar-applied fertilizers by leaves of 'Hass' avocado under Californiagrowing conditions, bloom was targeted. Low-biuret urea (50-54 lb/ acre, $46 \% \mathrm{~N}, \leq 0.25 \%$ biuret) and boron [B (1.4 lb/acre B as sodium tetraborate) ] applied at the cauliflower stage of inflorescence development, about the time of gametogenesis (pollen, ovule, and egg formation) (SalazarGarcía et al., 1998), increased ovule viability and the number of pollen tubes penetrating the ovule, respectively. There was a concomitant increase in total yield in response to both the foliar urea and boron fertilizer treatments (Jaganath and Lovatt, 1998; Lovatt, 1999). It is important to note that, unlike apple (Stover et al., 1999) and date palm (Khayyat et al., 2007) for which a combined bloom spray of urea plus boron increased yield, for avocado the combined treatment increased the number flowers with multiple carpels and had no effect on yield (Jaganath and Lovatt, 1998; Lovatt, 1999; S. Salazar-García, personal communication).

In the decade since this research was published, alternate bearing has become a significant economic problem that negatively impacts both citrus, especially consumer-popular seedless mandarin cultivars, and avocado production both in California and globally. Alternate bearing is typically initiated by the loss of crop because of a climatic event, which is then followed by a heavy on-crop 1 to 2 years later, depending on how long it takes the trees to recover. The alternating high yield on- and low-yield off-crops become entrained because of the inverse effect of the number of fruit in the developing crop on the number of inflorescences produced the next spring (Lovatt, 2010; Verreynne and Lovatt, 2009). In the on-crop year, there is a high proportion of small-size fruit with reduced commercial value. In contrast, fruit size is good in the off-crop year, but there are too few fruit to provide the grower with an adequate income. Foliar fertilizer treatments that could increase fruit size during a heavy on-crop year or increase flower number and fruit set during a light off-bloom year in an alternate bearing orchard would be of economic value to growers.

The efficacy of a winter prebloom foliar application of low-biuret urea to increase yield and fruit size in off- and on-crop years, respectively, of an alternate bearing 'Nules' Clementine mandarin orchard was determined. In addition, the effect of spring $(2 / 3$ leaf expansion or $10 \%$ anthesis) foliar applications of boron and zinc were tested based on their positive effects on fruit set and yield, most notably when low soil temperatures in spring would compromise uptake of soilapplied fertilizers (Batjer and Thompson, 1949; Brown et al., 1995; Gonzalez et al., 2010; Jaganath and Lovatt, 1998; Khayyat et al., 2007; Lovatt, 1999; Saran and Kumar, 2011; Sotomayor et al., 2002; Stover et al., 1999; Wells et al., 2008). To increase mandarin fruit size, three foliar applications of potassium nitrate (during ectodormancy, post-bloom, and exponential fruit growth) were tested (Boman, $2002)$. In light of the efficacy of potassium phosphite in increasing yield and fruit size of citrus cultivars (Albrigo, 1999; Lovatt, 1999), potassium phosphite and potassium phosphate, for comparison, were applied to cauliflower stage inflorescences of on- and off-bloom 'Hass' avocado trees. Foliar applications were compared with soilapplied phosphate to determine their capacity to increase fruit set and fruit size. The effects of these foliar fertilizer treatments on yield and fruit size have 
been published in part (Gonzalez et al., 2010; Zheng et al., 2013), but the data were not analyzed in the context of alternate bearing. Alternate bearing has been documented to influence results obtained with foliar-applied fertilizers; treatments increased yield in the on-crop year, which exacerbated the off-crop year of apple (Izadyar et al., 1998). In light of this and recent research showing that plant growth regulator treatments were effective in only off- or on-crop years of alternate bearing Clementine mandarin (Chao et al., 2011) and 'Hass' avocado orchards (Garner et al., 2011), respectively, it is critical to determine the effect of crop load on the capacity of properly timed foliar fertilizers to increase yield or fruit size.

\section{Materials and methods}

Mandarin. 'Nules' Clementine mandarin trees, 6 years from budding onto 'Carrizo citrange' rootstock ['Washington' navel orange (C. sinensis) $\times$ Poncirus trifoliata] were used in the research. The trees were in a commercial orchard in Fresno, CA (lat. $36^{\circ} \mathrm{N}$, long. $\left.119^{\circ} \mathrm{W}\right)$. The experimental design was a randomized complete block with 16 individual tree replications per treatment, which included: 1) N (23 $\mathrm{lb} /$ acre $\mathrm{N}$ as urea, $46 \% \mathrm{~N}, 0.25 \%$ biuret) prebloom in January; 2) B [1.3 lb/acre $\mathrm{B}$ as Solubor ${ }^{\circledR}$ (US Borax, Greenwood Village, CO), 20.5\% B] at 2/3-leaf expansion in April and 3) at $10 \%$ anthesis in the southwest tree quadrant in late April-early May; 4) zinc $(\mathrm{Zn})[81 \mathrm{lb} / \mathrm{acre} \mathrm{Zn}$ as zinc sulfate $\left.\left(\mathrm{ZnSO}_{4}\right), 36 \% \mathrm{Zn}\right]$ at $2 / 3$-leaf expansion and 5 ) at $10 \%$ anthesis in the southwest tree quadrant; 6) potassium $(\mathrm{K})[25 \mathrm{lb} /$ acre potassium nitrate $\left(\mathrm{KNO}_{3}\right)$ ] during ectodormancy (February), postbloom (75\% petal fall in the northwest tree quadrant, late May) and exponential fruit growth (July); and 7) untreated control, receiving no foliar application. Foliar fertilizers were applied to the foliage with a 400-psi handgun sprayer in $200 \mathrm{gal} /$ acre of water, adjusted to $\mathrm{pH}$ 5.5. The wetting agent (Silwett

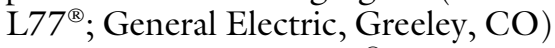
was added to the Solubor ${ }^{\circledR}$ and $\mathrm{ZnSO}_{4}$ solutions to a final concentration of $0.05 \%$. All trees received grower standard soil-applied fertilizer. At annual harvest in December, yield (pounds and number of fruit per tree) was determined. Subsamples of fruit were randomly selected from each of the 50 -lb bins of fruit harvested per tree so that each bin was equally represented in the subsample. A subsample of 100 fruit per tree was used to determine fruit diameter and fruit weight to calculate fruit size distribution. Fruit quality (peel thickness, percent juice, percent TSS, percent acidity, and TSS:acid ratio) was determined in a subsample of $\mathbf{2 5}$ fruit per tree by the University of California Lindcove Analytical Laboratory. Fruit were mechanically juiced with a commercial juice extractor; TSS concentration was determined with a refractometer; and percent acidity was determined by titration to $\mathrm{pH} 8.2 \pm$ 0.1 with $\mathrm{I} \mathrm{M}$ sodium hydroxide. The experiment was conducted for 2 years (consecutive).

Avocado. Eleven-year-old 'Hass' avocado trees, on 'Duke 7' clonal rootstock ( $P$. americana var. drymifolia) in a commercial orchard in Somis, CA (lat. $34^{\circ} \mathrm{N}$, long. $119^{\circ} \mathrm{W}$ ), were used in a randomized complete block design with 20 individual tree replications per treatment. Treatments included: 1) control-soil-applied potassium phosphate $[10.0 \mathrm{lb} /$ acre as phosphorus $(\mathrm{P})$ and $19.1 \mathrm{lb} /$ acre as $\mathrm{K}] ; 2$ ) foliar-applied potassium phosphate $(4 \mathrm{~N}-7.7 \mathrm{P}-14.9 \mathrm{~K}, 0.7 \mathrm{lb} /$ acre as $\mathrm{P}$ and $1.3 \mathrm{lb} /$ acre as $\mathrm{K}$ ); and 3 ) foliarapplied potassium phosphite $[0 \mathrm{~N}-$ 12.2P-21.6K (Nutra-Phite ${ }^{\circledR}$; Verdesian Life Science, Cary, NC), $0.7 \mathrm{lb} /$ acre as $\mathrm{P}$ and $1.25 \mathrm{lb} /$ acre as $\mathrm{K}]$. All treatments were applied at the cauliflower stage of inflorescence development (about March). Foliar fertilizers were applied in $200 \mathrm{gal} /$ acre of water $(\mathrm{pH}$ 5.5) with a 400-psi handgun sprayer. All trees received grower standard soil-applied fertilizer. In California, 'Hass' avocado fruit are harvested 10 to 18 months after bloom, when two separate crops are on the tree. Thus, each crop was treated at bloom and again as a nearly mature fruit before being harvested. At annual harvest in June, total yield (pounds and number of fruit) per tree was determined. A subsample of 100 fruit per tree, collected as described above, was used to determine fruit weight to calculate fruit size distribution. A subsample of two fruit per tree were ripened at 18 to $21{ }^{\circ} \mathrm{C}$; external fruit quality was evaluated for abnormalities and discoloration and internal fruit quality was evaluated for stem-end decay, gray spot and vascularization (presence of vascular bundles and associated fibers). Fruit quality parameters were rated on a scale from 0 (normal) to 4 (high incidence of abnormalities, discoloration, stem-end decay, gray spot, or vascularization). The experiment was conducted for 3 consecutive crop years (4 calendar years).

Alternate bearing index. To determine treatment effects on alternate bearing, the alternate bearing index $(\mathrm{ABI})$ was calculated for each data tree for consecutive harvests using the following equation: $\mathrm{ABI}=$ (Year 1 yield - Year 2 yield)/(Year 1 yield + Year 2 yield) in which yield was defined as total number of fruit per tree. ABI ranges from 0 (no alternate bearing) to 1 (complete alternate bearing) (Pearce and Dobersek-Urbanc, 1967).

Statistical analysis. Repeatedmeasures analysis was used to test for treatment effects on yield parameters and fruit quality with year as the repeated measure. Analyses were performed using the SAS statistical program (version 9.2; SAS Institute, Cary, NC). Analysis of variance was used to test for treatment effects on all yield parameters for a specific year and for cumulative yield and ABI. Means were separated using Fisher's protected least significant difference test at $P \leq$ 0.05 . Note that for cumulative yields, a missing datum point for a tree in any year excluded all data for that tree from the statistical analyses.

\section{Results}

MANDARIN. The ABI for the two crop years was 0.25 . Only when ABI exceeds 0.5 is alternate bearing considered an economic problem. The winter prebloom foliar application of low-biuret urea significantly increased the 2-year cumulative yield of commercially valuable size mandarin fruit (2.3-2.4 inches transverse diameter) as number $(P=0.020)$ and pounds of fruit per tree $(P=0.020)$ (Table 1$)$. The effect was due to a significant increase in the number $(P=0.027)$ and pounds $(P=0.028)$ of larger fruit per tree in the lower-yielding year and a numerical but nonsignificant increase in the yield of larger size fruit in the higher-yielding year $(>1000$ fruit per tree) (data not shown). No other foliar-applied fertilizer treatment increased fruit size, although boron applied at $2 / 3$ leaf expansion 
Table 1. Effect of foliar fertilizers applied at key stages of 'Nules' Clementine mandarin tree phenology on 2-year cumulative total yield and yield of commercially valuable size fruit. Application times refer to the following phenological stages: January, prebloom; February, dormancy; April, 2/3 leaf expansion; late April-early May, 10\% anthesis; late May, $75 \%$ petal fall; and July, exponential fruit growth. Control trees received no foliar treatment. All trees received the grower standard soil-applied fertilizer.

\begin{tabular}{|c|c|c|c|c|}
\hline \multirow[b]{2}{*}{ Foliar treatment } & \multirow[b]{2}{*}{ Application time } & \multirow{2}{*}{$\frac{\text { Total yield }}{\text { (no./tree) }}$} & \multicolumn{2}{|c|}{ Yield of fruit 2.3-2.4 inches diam ${ }^{y}$} \\
\hline & & & (no./tree) & $(\mathrm{lb} /$ tree $)$ \\
\hline Urea & January & $1873 \mathrm{a}^{\mathrm{z}}$ & $418 \mathrm{a}$ & $91.0 \mathrm{a}^{\mathrm{x}}$ \\
\hline Boron & April $(2 / 3$ leaf expansion $)$ & $1863 \mathrm{a}$ & $380 \mathrm{ab}$ & $82.9 \mathrm{ab}$ \\
\hline Zinc & April $(2 / 3$ leaf expansion $)$ & $1771 \mathrm{a}$ & 349 bc & $75.9 \mathrm{bc}$ \\
\hline Boron & Late April-early May ( $10 \%$ anthesis) & $1810 \mathrm{a}$ & $337 \mathrm{bc}$ & $73.5 \mathrm{bc}$ \\
\hline$P$ value & & 0.561 & 0.020 & 0.020 \\
\hline
\end{tabular}

${ }^{\mathrm{z}}$ Mean values within a column followed by different letters are significantly different at the probability value specified by Fisher's protected least significant difference test.

${ }^{y} \mathrm{l}$ inch $=2.54 \mathrm{~cm}, \mathrm{l} \mathrm{lb}=0.4536 \mathrm{~kg}$.

xAdapted from Zheng et al. (2013).

increased the number and pounds of commercially valuable size fruit per tree to a value intermediate to the winter prebloom foliar application of urea and the control trees receiving only soil-applied fertilizer. Foliar fertilizer treatments had no effect on the number or pounds of fruit in any other packing carton size category. Trees receiving winter prebloom foliarapplied urea produced the greatest total number and pounds of fruit per tree in both years of the research, but the difference was not significantly greater than the untreated control trees in either year or as 2-year cumulative total yield (Table 1). There were no treatment effects on ABI.

Consumers prefer fruit with a TSS:acid $\geq 12$. Fruit from trees in all treatments had TSS:acid $>14.0$ in Year 1 and $>17.5$ in Year 2. Winter prebloom foliar-applied urea and $\mathrm{Zn}$ at $10 \%$ anthesis tended to increase fruit TSS:acid annually. When averaged across years by repeated-measures analysis, these foliar fertilizer treatments resulted in fruit with significantly greater TSS:acid (>17.0) than fruit from trees treated with foliarapplied B at $2 / 3$ leaf expansion $($ TSS $:$ acid $=15.9)(P=0.086)($ data not shown). Foliar-applied fertilizers had no significant effects on other fruit quality parameters in a given year or when averaged across years.

Avocado. For avocado, alternate bearing in the research orchard was severe. The average ABI for the three consecutive crops was 0.88 . No foliarfertilizer treatment significantly changed the ABI. Foliar application of potassium phosphite at the cauliflower stage of inflorescence development significantly increased the 3-year cumulative yield of commercially valuable size fruit $(6.3-11.5 \mathrm{oz})$ as number $(P=$ $0.021)$ and pounds of fruit per tree $(P=0.007)$ (Table 2$).$ In addition, foliar-applied potassium phosphite increased the 3-year cumulative yield of larger size fruit $(7.5-12.5 \mathrm{oz})$ as both number $(P=0.017)$ and pounds of fruit per tree $(P=0.014)$ by 66 fruit and $33.2 \mathrm{lb}$, respectively, compared with untreated control trees. When averaged across the 3 years of the experiment by repeated-measures analysis, foliar-applied potassium phosphite increased the yield of commercially valuable size fruit as pounds, but not number, of fruit per tree $(P=0.070)$. This provides evidence that the treatment increased fruit size, not fruit set, and that the effect was independent of the large differences in annual crop load (fruit number per tree) in the severely alternate bearing orchard. Despite a significant increase in the yield of larger size fruit, foliar-applied potassium phosphite did not significantly increase 3 -year cumulative total yield as number or pounds of fruit per tree (Table 2). There were no significant effects attributed to fertilizer treatment on any fruit quality parameter analyzed in any year of the experiment.

\section{Discussion}

The results obtained in this research confirmed the efficacy of a winter prebloom foliar application of low-biuret urea to increase fruit size of 'Nules' Clementine mandarin (Gonzalez et al., 2010). The effect is consistent with the benefit of this treatment on the fruit size of the 'Washington' navel orange (Ali and Lovatt, 1994). In contrast to 'Washington' navel and 'Valencia' orange, the winter prebloom foliar application of urea did not increase total yield of 'Nules' Clementine mandarin trees in either experiment. The two experiments with 'Nules' Clementine mandarin were conducted in areas of

Table 2. Effect of potassium phosphate or potassium phosphite applied to cauliflower stage inflorescences of the 'Hass' avocado on 3-year cumulative total yield and yield of commercially valuable size fruit compared with control trees receiving soil-applied potassium phosphate at the same stage of tree phenology.

\begin{tabular}{|c|c|c|c|}
\hline \multirow[b]{2}{*}{ Treatment } & \multirow{2}{*}{$\frac{\text { Total yield }}{\text { (no./tree) }}$} & \multicolumn{2}{|c|}{ Yield of fruit $6.3-11.5 \mathrm{oz} /$ fruit $^{\mathrm{y}}$} \\
\hline & & (no./tree) & $(\mathrm{lb} /$ tree $)$ \\
\hline Potassium phosphate & $688 a^{z}$ & $448 \mathrm{~b}$ & $214.0 \mathrm{~b}^{\mathrm{x}}$ \\
\hline Potassium phosphite & $717 \mathrm{a}$ & 531 a & $256.3 \mathrm{a}$ \\
\hline Control-soil-applied & $702 \mathrm{a}$ & $457 \mathrm{~b}$ & $217.5 \mathrm{~b}$ \\
\hline
\end{tabular}

potassium phosphate

$P$ value 0.925

0.021

0.007

${ }^{\mathrm{z}}$ Mean values within a column followed by different letters are significantly different at the probability value specified by Fisher's protected least significant difference test.

${ }^{y} 1 \mathrm{oz}=28.3495 \mathrm{~g}, \mathrm{l} \mathrm{lb}=0.4536 \mathrm{~kg}$.

${ }^{\mathrm{x}}$ Adapted from Gonzalez et al. (2010). 
California with different microclimates and provided evidence that the optimal time of application was different, December in the area with the milder winter (Gonzalez et al., 2010 ) and January in the colder area (this study). In both experiments, the winter prebloom foliar application of urea had a significant effect on fruit size only when the crop load was less than 1000 fruit per tree. This result is consistent with recent research showing that gibberellic acid $\left(\mathrm{GA}_{3}\right)$ was effective only in the low-yield year (less than 1000 fruit per tree) of an alternate bearing Clementine mandarin orchard (Chao et al., 2011). The effect of crop load on the response of Clementine mandarin to foliar fertilizer and $\mathrm{GA}_{3}$ treatments is likely due to the differences in the number of flowers produced at bloom in the lower and higher yield years. The intense bloom resulted in a large number of fruit being set, with or without foliar-applied urea or $\mathrm{GA}_{3}$, which likely saturated the carrying capacity of the trees, making it difficult to enhance fruit set further. This is consistent with previous findings showing that yield is dependent largely on the initial number of flowers at bloom (Chao et al., 2011; Hanke et al., 2007). With so many fruit per tree competing for resources in the on-crop year, increasing fruit size proved difficult with foliar fertilizers (Gonzalez et al., 2010) and $\mathrm{GA}_{3}$ (Chao et al., 2011). In the light bloom year, the winter prebloom foliar application of urea had a positive, but not significant, effect on fruit set of 'Nules' Clementine mandarin, resulting in the greatest total yield as number of fruit per tree compared with all other treatments in both years of the experiment (not significant). The capacity of the treatment to increase yield of commercially valuable size fruit in the low-yield year was likely due to supplying nitrogen early in the season to support fruit growth at the cell division stage of fruit development.

In this experiment, spring applications of boron or zinc at $2 / 3$ leaf expansion or $10 \%$ anthesis did not increase fruit set or fruit size of 'Nules' Clementine mandarin. This is not surprising given that in most cases yield benefits were derived from applying boron and/or zinc to seeded fruit or nut crops (Batjer and Thompson, 1949; Brown et al., 1995; Jaganath and Lovatt, 1998; Khayyat et al., 2007; Lovatt, 1999; Saran and Kumar, 2011; Sotomayor et al., 2002; Stampar et al., 1999; Stover et al., 1999; Talaie and Taheri, 2001; Wargo et al., 2003; Wells et al., 2008; Wojcik et al., 2008) although boron might improve fruit size by increasing cell division (Waqar et al., 2009). For citrus, foliar fertilizers applied at the standard 2/3 leaf expansion stage (March) target a thin cuticle and large surface area and have been shown previously to achieve yields equal to soil fertilization (Embleton and Jones, 1974).

Whereas potassium has long been known to increase fruit size of citrus cultivars, including mandarin cultivars (Boman, 2002), multiple foliar sprays of water have been documented to reduce total yield and yield of commercially valuable size fruit of 'Nules' Clementine mandarin (Zheng et al., 2013). The interaction between these positive and negative effects might explain why the trees receiving three applications of potassium nitrate produced fewer commercially valuable size fruit than trees receiving a single application of urea winter prebloom, but not significantly fewer than the control trees.

The cauliflower stage of inflorescence development of the 'Hass' avocado has previously proven responsive to foliar fertilizers (Jaganath and Lovatt, 1998; Lovatt, 1999). Whereas a single application of boron or urea increased 3-year cumulative total yield per tree, with a significant effect on yield only in the on-crop year, in this experiment a single foliar application of potassium phosphite increased the 3-year cumulative yield of commercially valuable large fruit, with a significant effect only in the off-crop year (Lovatt, 1999). However, repeatedmeasures analysis provided evidence of the tendency of phosphite applied at this stage of tree phenology to increase fruit size across all 3 years of the research. The physiological basis for the increase in fruit size in response to the bloom phosphite application was not investigated in this experiment. Research has shown that phosphite is more readily absorbed into plant tissues than phosphate, including citrus and avocado leaves that are notoriously impervious to phosphate, and that foliar applications of phosphite can replace phosphate in citrus and avocado through chemical oxidation or by the action of oxidizing bacteria and fungi associated with the leaves (Lovatt and Mikkelsen, 2006). In addition, phosphite upregulates the shikimic acid pathway, which produces three essential amino acids; indole-3-acetic acid; salicylic acid; a broad spectrum of phenols, antioxidants, and other secondary metabolites; and lignin.

Taken together, the results of this research showed that properly timed foliar fertilizer applications successfully increased the yield of commercially valuable size fruit of 'Nules' Clementine mandarin and 'Hass' avocado in an alternate bearing orchard. For 'Nules' Clementine mandarin, a single winter prebloom foliar application of low-biuret urea increased the yield of fruit with transverse diameters between 2.3 and 2.4 inches by 13,200 fruit $(2860 \mathrm{lb})$ per 200 trees per acre for 2 years. For 'Hass' avocado, a single foliar application of potassium phosphite increased the yield of fruit weighing 6.3 to $11.5 \mathrm{oz}$ by 8140 fruit (4268 lb) per 110 trees per acre for 3 years. These results support the idea that specific nutrients applied to the foliage, including flowers, can efficiently meet crop nutrient demand and stimulate specific metabolic and physiological processes resulting in increased fruit set and/or fruit size and quality and grower income. The foliar fertilization strategies reported herein were cost effective and have the potential to reduce nutrient accumulation in the soil, runoff water, surface water, and groundwater. With the increasingly high cost of fertilizer, replacing soilapplied fertilizers in part with properly timed foliar fertilizers provides growers with a tool to reduce fertilizer use and expense while increasing yield and revenue and protecting the environment.

\section{Literature cited}

Albrigo, L.G. 1999. Effects of foliar applications of urea or Nutri-Phite on flowering and fields of Valencia orange trees. Proc. Florida State Hort. Soc. 112:1-4.

Ali, A.G. and C.J. Lovatt. 1994. Winter application of low-biuret urea to the foliage of 'Washington' navel orange increased yield. J. Amer. Soc. Hort. Sci. 119:1144-1150.

Batjer, L.P. and A.H. Thompson. 1949. Effect of boric acid sprays during bloom 
upon the set of pear fruits. Proc. Amer. Soc. Hort. Sci. 53:141-142.

Boman, B.J. 2002. $\mathrm{KNO}_{3}$ foliar application to 'Sunburst' tangerine. Proc. Florida State Hort. Soc. 115:6-9.

Brown, P.H., L. Ferguson, and G. Picchioni. 1995. Boron boosts pistachio yields. Fluid J. 3:11-13.

Chao, C.-C.T., T. Khuong, Y. Zheng, and C.J. Lovatt. 2011. Response of evergreen perennial tree crops to gibberellic acid is crop load-dependent: I. $\mathrm{GA}_{3}$ increases the yield of commercially valuable 'Nules' Clementine mandarin fruit only in the off-crop year of an alternate bearing orchard. Sci. Hort. 130:753-761.

Embleton, T.W. and W.W. Jones. 1974. Foliar-applied nitrogen for citrus fertilization. J. Environ. Qual. 3:388-392.

Garner, L.C., G.J. Klein, Y. Zheng, T. Khuong, and C.J. Lovatt. 2011. Response of evergreen perennial tree crops to gibberellic acid is crop load-dependent: II. $\mathrm{GA}_{3}$ increases yield and fruit size of 'Hass' avocado only in the on-crop year of an alternate bearing orchard. Sci. Hort. 130:743-752.

Gonzalez, C., Y. Zheng, and C.J. Lovatt. 2010. Properly timed foliar fertilization can and should result in a yield benefit and net increase in grower income. Acta Hort. 868:273-286.

Hanke, M.-V., H. Flachowsky, A. Peil, and C. Hättasch. 2007. No flowers no fruit: Genetic potentials to trigger flowering in fruit trees. Genes Genomes Genomics $1: 1-20$.

Izadyar, A.B., M.J. Malakouti, A.R. Talaie, and E. Fallahi. 1998. Biennial bearing and protein content of apples as influenced by high concentrations of foliar nitrogen and sulfur. J. Plant Nutr. 21:649-653.

Jaganath, I. and C.J. Lovatt. 1998. Efficacy studies on prebloom canopy applications of boron and/or urea to Hass avocado. Proc. 3rd World Avocado Congr. 1:181-184

Kallsen, C. 2007. Pistachio notes. Univ. California Coop. Ext. Mar. 2007.

Khayyat, M., E. Tafazoli, S. Eshghi, and S. Rajaee. 2007. Effect of nitrogen, boron, potassium and zinc sprays on yield and fruit quality of date palm. American-Eurasian J. Agr. Environ. Sci. 2:289-296.

Kumar, A.R. and N. Kumar. 2007. Sulfate of potash foliar spray effects on yield, quality and post-harvest life of banana. Better Crops 91:22-24.

Lester, G.E., J.L. Jifon, and W.M. Stewart. 2007. Foliar potassium improves cantaloupe marketable and nutritional quality. Better Crops 91:24-25.

Lord, E.M. and K.J. Eckard. 1987. Shoot development in Citrus sinensis L. (Washington navel orange). II. Alteration of developmental fate of flowering shoots after $\mathrm{GA}_{3}$ treatment. Bot. Gaz. 148:17-22.

Lovatt, C.J. 1999. Timing citrus and avocado foliar nutrient applications to increase fruit set and size. HortTechnology 9:607-612.

Lovatt, C.J. 2010. Alternate bearing of 'Hass' avocado: A summary of basic information to assist growers in managing their orchards. California Avocado Soc. Yrbk. 93:125-140.

Lovatt, C.J. and R.L. Mikkelsen. 2006. Phosphite fertilizers: What are they? Can you use them? What can they do? Better Crops 90:11-13.

Pearce, S.C. and S. Dobersek-Urbanc. 1967. The measurement of irregularity in growth and cropping. J. Hort. Sci. 42:295-305.

PureGro Company. n.d. Soil vs. foliar. PureGro Co., Sacramento, CA.

Salazar-García, S., E.M. Lord, and C.J. Lovatt. 1998. Inflorescence and flower development of the 'Hass' avocado ( $\mathrm{Per}$ sea americana Mill.) during "on" and "off” crop years. J. Amer. Soc. Hort. Sci. 123:537-544.

Saran, P.L. and R. Kumar. 2011. Boron deficiency disorders in mango (Mangifera indica): Field screening, nutrient composition and amelioration by boron application. Indian J. Agr. Sci. 81:506-510.

Son, T.T., L.X. Anh, Y. Ronen, and H.T. Holwerda. 2012. Foliar potassium nitrate application for paddy rice. Better Crops 96:29-31.
Sotomayor, C., H. Silva, and J. Castro. 2002. Effectiveness of boron and zinc foliar sprays on fruit setting of two almond cultivars. Acta Hort. 591:437-440.

Stampar, F., M. Hudina, K. Dolenc, and V. Usenik. 1999. Influence of foliar fertilization on yield quantity and quality of apple (Malus domestica borkh.), p. 91-94. In: D. Anac and P. Martin-Prével (eds.). Improved crop quality by nutrient management. Kluwer Academic Publishers, Dordrecht, The Netherlands.

Stover, E., M. Fargione, R. Risio, W. Stiles, and K. Iungerman. 1999. Prebloom foliar boron, zinc and urea applications enhance cropping of some 'Empire' and 'McIntosh' apple orchards in New York. HortScience 34:210-214.

Talaie, A. and M. Taheri. 2001. The effect of foliar spray with $\mathrm{N}, \mathrm{Zn}$ and $\mathrm{B}$ on fruit set and cropping of Iranian local olive trees. Acta Hort. 564:337-341.

Verreynne, J.S. and C.J. Lovatt. 2009. The effect of crop load on bud break influences return bloom in alternate bearing 'Pixie' mandarin. J. Amer. Soc. Hort. Sci. 134:299-307.

Waqar, A., A. Niaz, S. Kanwal, M. Rahmatullah, and M.K. Rasheed. 2009. Role of boron in plant growth: A review. J. Agr. Res. 47:329-338.

Wargo, J.M., I.A. Mervin, and C.B. Watkins. 2003. Fruit size, yield, and market value of 'Goldrush' apple are affected by amount, time and method of nitrogen fertilization. Hort Technology 13:153-161.

Wells, M.L., P.J. Conner, J.F. Funderburk, and J.G. Price. 2008. Effects of foliarapplied boron on fruit retention, fruit quality, and tissue boron concentration of pecan. HortScience 43:696-699.

Wojcik, P., M. Wojcik, and K. Klamkowski. 2008. Response of apple trees to boron fertilization under conditions of low soil boron availability. Sci. Hort. 116: 58-64.

Zheng, Y, T. Khuong, C.J. Lovatt, and B.A. Faber. 2013. Comparison of different foliar fertilization strategies on yield, fruit size and quality of 'Nules' Clementine mandarin. Acta Hort. 984:247-255. 